\title{
The Adventure of BipBop: An Android App Pathfinding Adventure Game
}

\author{
Gredion Prajena ${ }^{1, *}$, Jeklin Harefa ${ }^{1}$, Andry Chowanda $^{2}$, Alexander $^{1}$, Maskat ${ }^{1}$, Kamal Rahman $^{1}$, Muhammad Naufal Fadhil ${ }^{1}$ \\ ${ }^{1}$ Computer Science Department, School of Computer Science, Bina Nusantara University, Jakarta, Indonesia 11480 \\ ${ }^{2}$ Game Application Technology Department, School of Computer Science, Bina Nusantara University, Jakarta, Indonesia 11480
}

\begin{tabular}{l} 
A R T I C L E I N F O \\
\hline Article history: \\
Received: 27 December, 2019 \\
Accepted: 07 February, 2020 \\
Online: 23 March, 2020 \\
\hline Keywords: \\
Adventure Puzzle, Culture Game, \\
Artificial Intelligence, \\
* algorithm, \\
Traditional House \\
\hline
\end{tabular}

\begin{abstract}
A B S T R A C T
The purpose of this research is to build an android based pathfinding adventure game where user gets information about Indonesian culture, especially the traditional houses including the folk songs and the traditional weapons in certain areas. The method used is by questionnaires, interviews, observation, and literature study. This application also implements the $A^{*}$ algorithm to solve the pathfinding problems. The result of this research is "The Adventure of BipBop" app that can make the user can feel the experience of playing that is not only entertaining but also as a medium to convey about the culture of Indonesia and help preserve the traditional house of Indonesia. Most of the respondents find out that the application can provide Indonesian culture well (91.7\%). Furthermore, this application can realize about $84.5 \%$ of players to help preserve the traditional culture in Indonesia.
\end{abstract}

\section{Introduction}

Nowadays, technology has been evolved tremendously in many aspects, especially in smartphones. With this evolving technology, the lifestyle especially in working and collaborating with someone else has become easier [1]. Almost every person has a smartphone, especially those who live in a city. Research in 2016 figure out the number of smartphones equivalent to one for every fifth person on earth [2]. Smartphone operating system still dominated by Android which has 75.27\% market share worldwide in May 2019 [3]. With a smartphone, we can do many activities like communication, entertainment, finance, shopping, and play game. Among those activities, playing games remains one of the most engaging categories for smartphone users [4] and Gaming is the main entertainment feature on a smartphone [5]. The game does not only serve as entertainment but also allows the player to learn about many things [6] [7]. Pathfinding is a common feature for various applications including games. Pathfinding generally refers to find the shortest route between two endpoints [8]. Some pathfinding algorithms, like Depth-First Search (DFS), BreadthFirst Search (BFS), Hill-Climbing Search, Djikstra's, A Star (*) algorithm was created for solving the pathfinding problem. Based on those popular pathfinding algorithms, the $\mathrm{A}^{*}$ algorithm considered as the most popular pathfinding algorithm in Artificial Intelligence Games and widely used in pathfinding and graph traversal [9]. Hence, this paper will use $A^{*}$ for the enemy to chasing after player inside this game.

${ }^{*}$ Gredion Prajena, Email: gprajena@binus.edu
As the largest archipelago country in the world, Indonesia has a variety of cultures, ranging from the local, national, or even the foreign culture that existed before Indonesia's independence. The manifestations of the diversity of Indonesian cultures consist of traditional houses, traditional dances, traditional clothing, folk songs, traditional musical instruments, performing arts, and folklore [10]. However, currently, the world is facing the 4T revolution (Technology, Telecommunication, Transportation, Tourism) that has dominant globalizing force so that the boundaries between regions are increasingly blurred and lead to the creation of a global village as predicted by McLuhan (McLuhan is a popular communication scientist and critic because the concept is about the global village, medium is the message and its predictions about the World Wide Web 30 years before it was discovered). This condition raises problems in the weakening of cultural heritage [11]. One example of the fading of Indonesian culture is the traditional houses. This can be seen from the news about traditional houses in Indonesia. News from merdeka.com said, Lontiok tourism house located on Kuok Belimbing Island, Bangkinang Barat District, Kampar Regency, Riau. If it was once famous for its antique, it is now weathered because it is not maintained [12]. Besides, based on the information obtained from the news portal makassar.tribunnnews.com also wrote, the condition of the Wotu traditional house in Wotu Sub-District, East Luwu, South Sulawesi, was left abandoned by the government. Around the traditional house which has 72 concrete pillars already overgrown with wild plants, many roofs have been dislodged, new floors and walls have been installed 50 percent. The development 299 


\section{G. Prajena et al. / Advances in Science, Technology and Engineering Systems Journal Vol. 5, No. 2, 299-304 (2020)}

has stopped for 7 years ago [13]. Then, at the end of January 2018, there was news about the Toraja Traditional House in the Benteng Somba Opu area which suffered severe damage to the roof and floor because it was not maintained so it looked alarming [14].

To overcome the fading of Indonesian culture, it needs synergic participation from parents, society, education, and government as an effort to respect the regional culture by providing knowledge of local culture to children and implemented as part of daily life [15]. By utilizing sophisticated technology, and with the increase in the gaming industry on smartphones, a game about Indonesian culture that can restore the interest of many people to love Indonesian culture. There are several kinds of research that have been done to make an application about learning Indonesian culture through games based on android. Alexander et. al. developed "Indonesian National Culture", a puzzle that takes the theme of Indonesian Culture with helping the younger generation get to know and maintain various cultures in Indonesia. Besides that, this puzzle game also can be used as a learning media.

From the background and reference studies that have been explained, this paper wants to increase user awareness about Indonesian culture by building a game adventure puzzle with the Indonesian culture theme, especially in the traditional house. Specifically, the traditional houses that will be focused on this research, including Central Java, West Java, Irian Jaya, West Sumatera, and Bali. Users will have given task through the storyline to fix the broken traditional house by collecting material in the game. And, this game will have information about the traditional house and some information about the culture in the corresponding area. To make the app more challenging, this game will implement Artificial Intelligence pathfinding. This app named The Adventure of BipBop.

From the formulation of the problem, this paper contributes to providing knowledge and information about Indonesian culture through the game. Hence, can increase the level of awareness and interest of the community in helping to preserve traditional houses. This paper also gives the exploration and variety of adventure games based on Android with Pathfinding.

\section{Recent Work}

Artificial Intelligence and Level Design in-game task demand increasingly [16] because Artificial Intelligence and Level Design can make the game more fun and challenge. Pathfinding is one of the Artificial Intelligence that can be implemented in various applications especially in-game. In this game, Pathfinding Algorithm is used for moving the object from the starting point to endpoint in this research Pathfinding will move the enemy from the initial location to the player. For Level Design, the Adventure of BipBop will have several tasks that use traditional houses and use islands in Indonesia. The research said one of the important things to build successful serious games is engaging the learners [17]. With Pathfinding and Level Design, this game is expected can have good user engagement.

From the journal entitled "Android Based Indonesian Information Culture Education Game" by Kidi, et. al. explain about an educational game called "Merah Putih". In this game, the player will become an Indonesian citizen character who meets with a foreign citizen named Robert who invites the player to accompany him around to the areas in Indonesia. Inside the game, players will select existing stages by selecting areas on the map in Indonesia. A map is divided into ten areas that can be entered by players. Each stage of the game will consist of three games where two games are varied and different sets for each stage, and there is a quiz at the end of the game to hone the player's ability to get to know the culture in Indonesia. There is also a new hidden bonus game that will open when the player gets the perfect score for a stage. When the player finishes running and plays a stage, then the player will get a reward in the form of objects where the object can be seen in the collection of players and players can see information about the objects that have been obtained and information about the province. Objects collected are usually common objects that come from areas in Indonesia. Besides the player will also get a star per the value obtained after the player finished playing a stage. Stars can be collected and later used to upgrade the game to assist players in completing the game [18].

In a journal entitled "Indonesian Culture Learning Application Based on Android" by [19] explained the game application called "Indonesian National Culture". This game is a puzzle that takes the theme of Indonesian culture. This game aims to help the younger generation get to know various cultures in Indonesia and maintain a historical culture native to Indonesia. Besides, the game has a function as a learning media obtained from several studies conducted (Setiawan, Handojo, \& Hadi, 2017). This application is divided into several menus, namely Learn, Quiz, Game, Login, Gallery, Exit. Quiz menu is a game in the form of a quiz to test the knowledge of users related to the scope of culture discussed in the game application. The cultural elements in this game are traditional dance, traditional house, and historical place.

Those 2 research create 2D puzzle game applications regarding Indonesian Culture Learning Based on Android, and this paper will use a $3 \mathrm{D}$ puzzle game with a pathfinding algorithm, hence can engage the player and give different experiences in learning Indonesian Culture.

\section{Proposed Method}

This research will be divided into three stages. The first stage is requirement analysis and concept story design, where the initial study performed by surveying the respondents and analyze the result to design the game concept. The second stage is preparing all the asset including visual, audio, and build the app using Unity. And finally, the last stage is the evaluation of the proposed game.

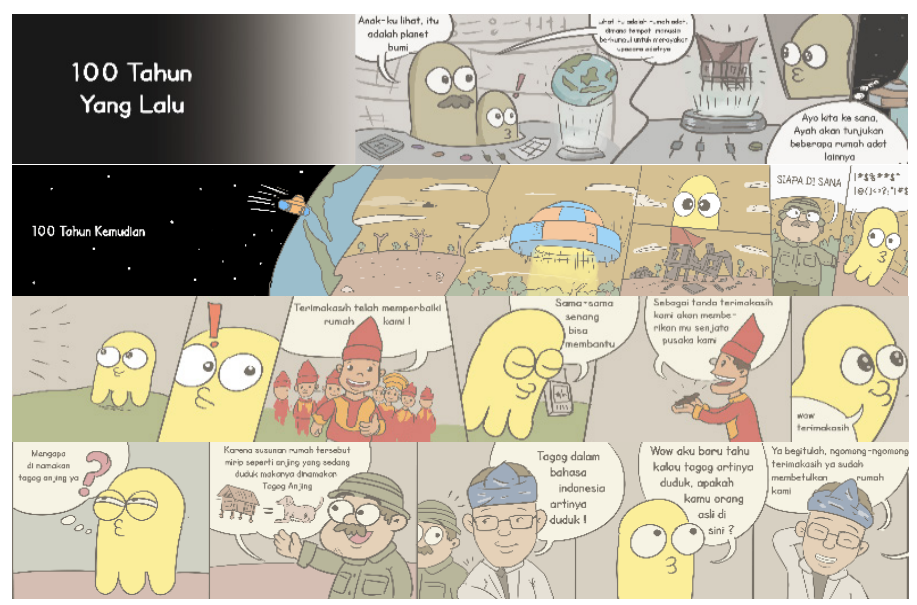

Figure 1. Story 
In the first stage, the initial study was performed by surveying 255 respondents $(52.2 \%$ are male) with most of them are the students in the higher education system. In the survey, most respondents (72.9\%) are using Android for their mobile operating system. While for the game genre, $43.9 \%$ of them like to play adventure games and $52.6 \%$ of them interested in an adventure puzzle game with Indonesia's traditional house themed.

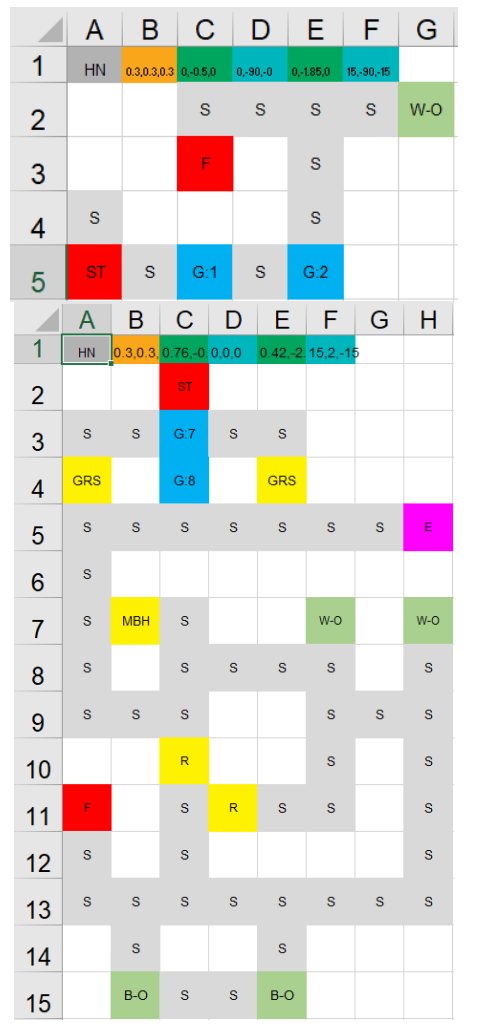

Figure 2. Map for Level 1 Stage $1 \&$ Level 5 Stage 3

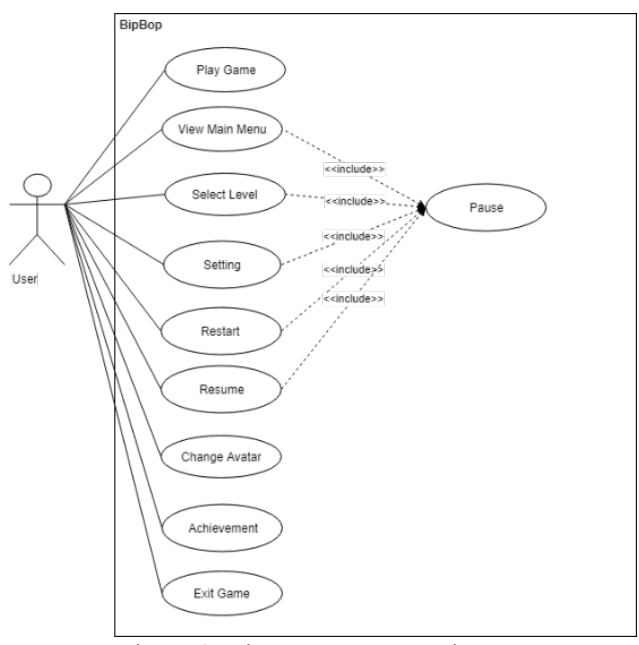

Figure 3. BipBop Use Case Diagram

The second stage is developing the asset, app, map, level design, features, and algorithm. This game will have ten features (see FIGURE 3). This game started with a story about a space creature called BipBop that come to earth and accidentally found the traditional house in Indonesia. Unconsciously, He interested in it, but He must leave earth to avoid known by a human (see FIGURE 1). After one hundred years passed by, He comes again to earth and discovers traditional houses have been broken. He wants to help human to fix it by collecting the material needed. This game will use a combination of adventure and puzzle genre and use maps for playing area. This game will have 5 main levels, where for each level there will have 3 stages and each stage will have different maps. The game map needs to be well prepared or pre-processed before the A* algorithm can work [9], the example map of each stage can be seen in Figure 2. TABLE 1 shows the description of each variable columns:

Table 1. Variable Map Description

\begin{tabular}{|c|c|}
\hline Column & Description \\
\hline $\mathrm{A} 1(\mathrm{HN})$ & prefab model from the traditional house \\
\hline B1 & $\begin{array}{l}\text { size / scale of the traditional house model with } \\
\text { format of } x, y, z\end{array}$ \\
\hline $\mathrm{C} 1$ & $\begin{array}{l}\text { position of a traditional house with the format of } \\
x, y, z\end{array}$ \\
\hline D1 & $\begin{array}{l}\text { rotation of traditional house with the format of } \\
x, y, z\end{array}$ \\
\hline E1 & $\begin{array}{l}\text { position of the traditional house when it's } \\
\text { damaged with the format of } x, y, z\end{array}$ \\
\hline F1 & $\begin{array}{l}\text { rotation of traditional house when it's damaged } \\
\text { with the format of } x, y, z\end{array}$ \\
\hline $\begin{array}{l}\text { S (grey } \\
\text { color) }\end{array}$ & $\begin{array}{l}\text { The passable road by both the player and the } \\
\text { enemies }\end{array}$ \\
\hline $\begin{array}{l}\text { ST (red } \\
\text { color) }\end{array}$ & the starting point of the player \\
\hline $\begin{array}{l}\text { F (red } \\
\text { color) }\end{array}$ & $\begin{array}{l}\text { the checkpoint where the player aims to complete } \\
\text { the game }\end{array}$ \\
\hline $\begin{array}{l}\mathrm{W}-\mathrm{O} / \mathrm{B}- \\
\mathrm{O} \text { (green } \\
\text { color) }\end{array}$ & $\begin{array}{l}\text { the position of the materials (W-O for wood; B-O } \\
\text { for brick) }\end{array}$ \\
\hline $\begin{array}{l}\mathrm{R} \text { (yellow } \\
\text { color) }\end{array}$ & the position of the stone (obstacle) \\
\hline $\begin{array}{l}\text { MBH } \\
\text { (yellow } \\
\text { color) }\end{array}$ & the position of the moving box (horizontally) \\
\hline $\begin{array}{l}\text { GRS } \\
\text { (yellow } \\
\text { color) }\end{array}$ & $\begin{array}{l}\text { the position of the grass (BipBop can hide behind } \\
\text { the grass to avoid the enemies) }\end{array}$ \\
\hline $\begin{array}{l}\text { E (pink } \\
\text { color) }\end{array}$ & the position of the enemy \\
\hline $\begin{array}{l}\text { G:x (blue } \\
\text { color) }\end{array}$ & $\begin{array}{l}\text { the position of trigger guide screen based on the } \\
\text { number. } \\
\text { Number } 7 \text { : Be Careful, don't let you get close to } \\
\text { the enemy } \\
\text { Number } 8 \text { : The grass will help you to hide from } \\
\text { the enemy }\end{array}$ \\
\hline
\end{tabular}

For each stage, the player must collect all the items and go to checkpoint. Besides, there will be a different level of difficulty and the enemies who will always chase the player by using the $A^{*}$ pathfinding algorithm (see FIGURE 4). A* algorithm will be used to move the enemy from the initial location to the player location and prevent the enemy from obstacles. As we see in FIGURE 4, first the algorithm will check if the enemy needs to search player location. If the player location is found, the enemy will move to the player, if not the enemy will move randomly. Then the algorithm will detect nodes to find the closest path to the player. And after that, the algorithm will find the closest path from enemy 
to player by avoiding the obstacles. The algorithm will run continuously chasing the player, even when the player moving.

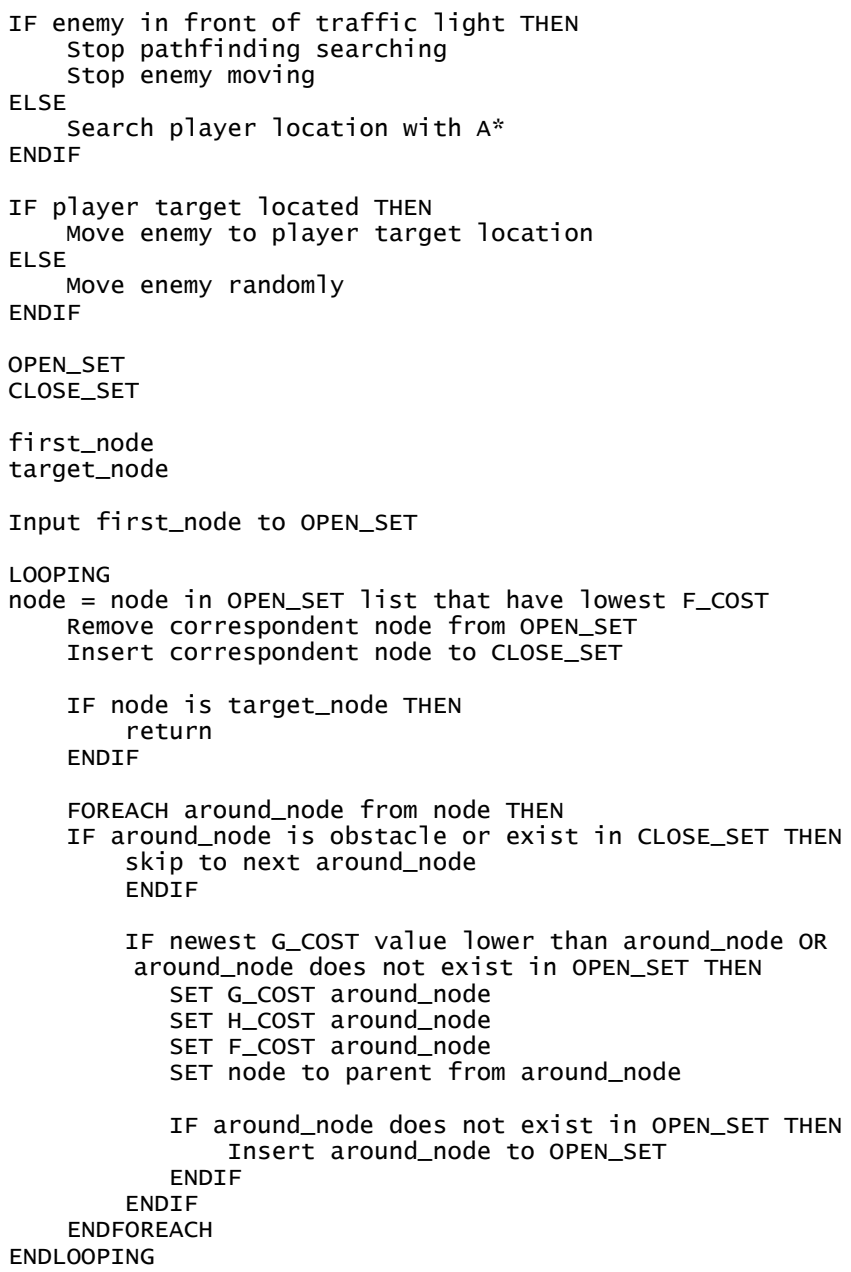

Figure 4. Pseudocode for Pathfinding Algorithm

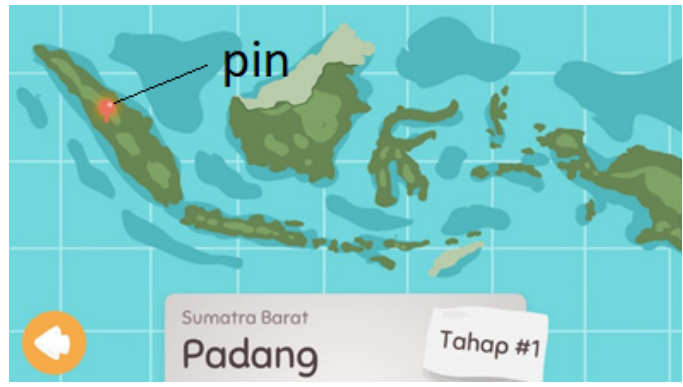

Figure 5. Map of Indonesia

There are 34 traditional houses in Indonesia [20] and the proposed game will use 5. The first level is Rumah Gadang from West Sumatra, and the player must finish all stages to continue to the next level. After the player finishes all stages, then the proposed game will show the map of Indonesia with a pinned location (see FIGURE 5). The second level is Rumah Adat Tagog Anjing from West Java. The third level is Rumah Adat Joglo from Central Java. The fourth level is Rumah Adat Bali from Bali. The fifth level is Rumah Adat Honai from Papua. When finished all the stages, the player will get a new item from the villages and the proposed game will show a description of the item and house.
During playing the game, the player can pause or reset to the initial condition.

In the third stage, the proposed game was evaluated using a questionnaire. Based on the questionnaire distributed, the number of respondents is 60 , and most of them are university students. The detailed results of the questionnaire are described in the next section.

\section{Result and Discussion}

In this section the game has been developed, when the player opens the app it will show four menus (see FIGURE 6), achievement (trophy icon), change character color (paint roller icon), settings (gear icon), and Start (button "mulai"). The achievement will show items given to the player when finishing a certain level. The default color of BipBop character is yellow but the player can change the color by choosing icon paint or change character color, and the player will be provided various colors to choose. In settings, the player can configure to turn on/off the music and the sound effect, besides change the control position and reset the game data. When the player chooses button Start, it will bring the player to the game. For the initial set, the player will see the story of the space creature called BipBop that comes to earth and discover the traditional house. After that, the game starts with a game guide such as how to control the character, how to collect items, tips, and how to finish the stage. For the first level, the player will play in West Sumatra. The game area of the given map is the land above the sea, the player needs to move the character by using game control shown on the screen. If the character moves out of the land, the character will sink then the game will stop and show time spent. The player can repeat the game without limits and the game will update the best time for each stage. During the game, the player also can pause by pushing the top left corner button, the player can reset position to the initial, and exit to the menu. Each level in this game consists of 3 stages, and after the player finishes one level, the player will get items and can go to the next level (see FIGURE 6). The difficulties of the game will increase along with the level, various obstacles will appear in every level such as some boxes that will block the movement of the player, so the player needs to move the box first, the box can use as a foothold as well. Another obstacle is the enemy that can chase the BipBop character, if the enemy hits the BipBop then the player loses. The enemy will move to chase the player with $\mathrm{A}^{*}$ pathfinding algorithm, hence it will chase wherever the player moves. This game will store data to file-based database [21], the detail column of the data can be seen in TABLE 2.

Table 2. BipBop File Database

\begin{tabular}{|l|l|l|}
\hline Variable Name & $\begin{array}{l}\text { Variable } \\
\text { Type }\end{array}$ & Description \\
\hline CURRENT_STAGE & Integer & $\begin{array}{l}\text { Determine the stage that } \\
\text { will be used when starting } \\
\text { the game }\end{array}$ \\
\hline CURRENT_LEVEL & Integer & $\begin{array}{l}\text { Determine the level to be } \\
\text { used when starting the } \\
\text { game }\end{array}$ \\
\hline
\end{tabular}


G. Prajena et al. / Advances in Science, Technology and Engineering Systems Journal Vol. 5, No. 2, 299-304 (2020)

\begin{tabular}{|l|l|l|}
\hline Variable Name & $\begin{array}{l}\text { Variable } \\
\text { Type }\end{array}$ & Description \\
\hline LEVEL_STATE & Integer & $\begin{array}{l}\text { Determine the game level } \\
\text { status, the status is (not } \\
\text { yet completed level) and 1 } \\
\text { (has completed level) }\end{array}$ \\
\hline TIME_ELAPSED & Float & $\begin{array}{l}\text { Save time spent when } \\
\text { completing the stage }\end{array}$ \\
\hline LAST_LEVEL & Integer & $\begin{array}{l}\text { Save the last progress } \\
\text { level of the player }\end{array}$ \\
\hline LAST_STAGE & Integer & $\begin{array}{l}\text { Save the last progress } \\
\text { stage of the player }\end{array}$ \\
\hline AFTER_FINISH & Integer & $\begin{array}{l}\text { Defines the screen when } \\
\text { you have finished the } \\
\text { game }\end{array}$ \\
\hline BEST_TIME_n & Float & $\begin{array}{l}\text { Save the best time for } \\
\text { each level (n) }\end{array}$ \\
\hline LEVEL_STATE_n & Integer & $\begin{array}{l}\text { Save the level status } \\
\text { played by level (n), the } \\
\text { status is 0 (not yet } \\
\text { completed level) and 1 } \\
\text { (has completed level) }\end{array}$ \\
\hline
\end{tabular}

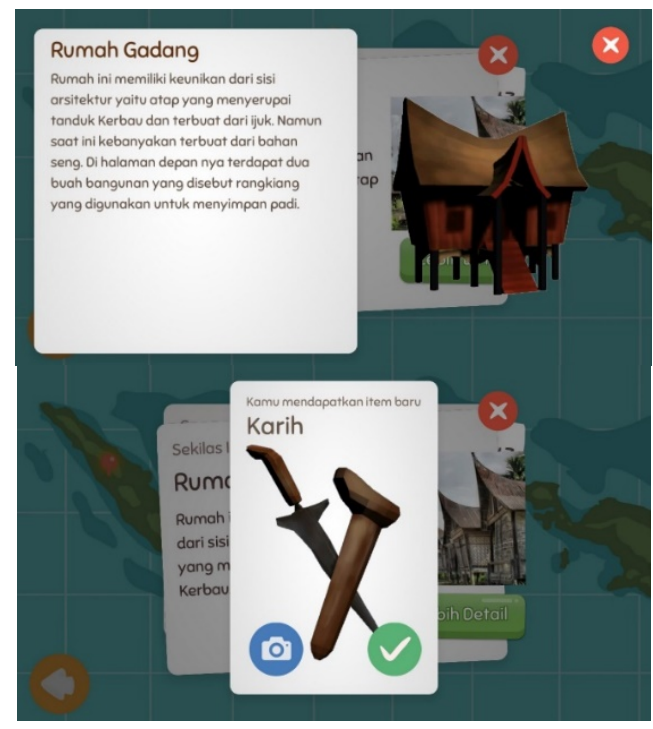

Figure 6. BipBop (Main Menu, Game Guide, Playing Game, Level Finish, Traditional House, Item)

This study evaluated by two methods, self-assessment and user-assessment. In the self-assessment evaluation, this game measured by 9 general principles of User Interface for games [22] as well as Five Measurable Human Factor [23] those assessments also supported by the user's questionnaire.

For evaluating user satisfaction, this study has conducted the survey using a questionnaire to sixty people chosen randomly. Respondents will get a link to the game app, try the game, and then fill the survey questions (see FIGURE 7). The result of the questionnaire more than half of the respondents agreed that this game is easy to operate ( $80 \%$ ), yet have good gameplay $(83.3 \%)$, game design (90\%) and features $(85 \%)$. They also affirm the instructions in the game are easy to understand (98.3\%). And then, this game makes them realize that the Indonesian traditional houses are now becoming obsolete $(80 \%)$ and this game also can become a medium to convey $(88.3 \%)$ and learn Indonesian culture $(91.7 \%)$. Finally, after they play this game, they interested to help preserve Indonesian traditional house (84.9\%).

\begin{tabular}{|l|l|}
\hline 1. Do you think this game & 6. Do you think this game has provided \\
is easy to operate? & information about Indonesian culture well? \\
a. Yes & a. Yes \\
b. No & b. No \\
2. Is the gameplay of this & 7. Do you think this game is appropriate as a \\
game good enough? & medium to convey Indonesian culture \\
a. Yes & especially in traditional houses? \\
b. No a. Yes & b. No \\
3. Are the features & b. No \\
provided good enough? & 8. Can you learn about Indonesian culture through \\
a. Yes & this game, especially about Indonesian \\
b. No instructions & traditional houses? \\
4. Are the Yes \\
given easy to & b. No \\
understand? & 9. Do you realize that through this game, \\
a. Yes & Indonesian traditional houses are now \\
b. No & becoming obsolete? \\
5. Do you think the design & a. Yes \\
of this game is good? & b. No \\
a. Yes & 10. Are you interested in this application to help \\
b. No No & preserve Indonesian traditional houses? \\
& a. Yes \\
b. No
\end{tabular}

Figure 7. Questionnaire Form 


\section{Conclusion and Future Work}

This research gives information about Indonesian culture especially in the traditional house called BipBop. This adventure and puzzle game has several features that support the player to save and pause the game, customize the character, and save the best time for each level. This game also has a game guide to help the player understand how to play, various difficulties with items and the enemy. Based on the evaluation conducted, the BipBop game can give information about Indonesian culture $(91.7 \%)$ and after trying this game, people realize that Indonesian traditional house is now becoming obsolete $(80 \%)$. The BipBop game also can act as a medium to convey $(88.3 \%)$ and learn $(91.7 \%)$ Indonesian traditional house. Moreover, this game can make the user interested to help preserve Indonesian traditional house $(84.9 \%)$. All these successes supported by the ease of operation the game (80\%), good gameplay (83.3\%), game design $(90 \%)$ and features $(85 \%)$. For future work, there are several improvements can be added to this game, such as adding multiplayer, more detail information about the culture and folk songs in a related area.

\section{Conflict of Interest}

The authors declare no conflict of interest.

\section{Acknowledgment}

This research is partially supported by BINUS University.

\section{References}

[1] E. Isabela, J. Drona, N. Fadhilah, D. F. Tanoto, J. Harefa, G. Prajena, A Chowanda and A., "NYAM: An Android Based Application for Food Finding Using GPS," in 3rd International Conference on Computer Science and Computational Intelligence 2018, Jakarta, 2018. https://doi.org/10.1016/j.procs.2018.08.189

[2] B. Carton, J. Mongardini and Y. Li, "A New Smartphone for Every Fifth Person on Earth: Quantifying the New Tech Cycle," IMF Working Paper, 2018.[Online].Available:

https://www.imf.org/ /media/Files/Publications/WP/2018/wp1822.ashx

[3] "Mobile Operating System Market Share Worldwide," 13 June 2019 [Online]. Available: http://gs.statcounter.com/os-marketshare/mobile/worldwide.

[4] "Smartphone Usage and Behaviour Report," Kantar IMRB \& MMA, 2016. [Online].Available:

https://www.mmaglobal.com/files/documents/mma kimrb smartphone re port_overview.pdf

[5] L.-F. Olatz, M. Niko, K. Maria, G. Mark and K. D. J., "Mobile gaming and problematic smartphone use: A comparative study between Belgium and Finland," Journal of Behavioral Addictions, pp. Volume 7, Issue 1, 2017. https://doi.org/10.1556/2006.6.2017.080

[6] M. Hartono, M. A. Candramata, K. N. Adhyatmoko and B. Yulianto, "Math Education Game for Primary School," 2016 International Conference on Information Management and Technology (ICIMTech), pp. 93-96, 2016. https://doi.org/10.1109/ICIMTech.2016.7930309

[7] Y. L. Prasetio, S. Rambito, A. Yudhistira, S. F. Aulia and A. Chowanda, "Teaching Social Critique to Adults with A Desktop Horror Myth Game," 3rd International Conference on Computer Science and Computational Intelligence 2018, pp. 2018. https://doi.org/10.1016/j.procs.2018.08.224

[8] X. Cui and H. Shi, "A*-based Pathfinding in Modern Computer Games," IJCSNS International Journal of Computer Science and Network Security, VOL.11 No.1, January 2011, pp. 125-130, 2011.
[9] N. H. Barnouti, S. S. M. Al-Dabbagh and M. A. S. Naser, "Pathfinding in Strategy Games and Maze Solving Using A* Search Algorithm," Journal of Computer and Communications, vol. 4, pp. 15-25, 2016. https://dx.doi.org/10.4236/jcc.2016.411002

[10] O. Indriani, M. Shaifuddin and M. , "UPAYA MENINGKATKAN KEMAMPUAN MENGIDENTIFIKASI KEANEKARAGAMAN BUDAYA INDONESIA MELALUI METODE TALKING STICK," Jurnal Didaktika Dwija Indria (SOLO), (Vol 1, No 3 (2013): JULI, Jurnal Mahasiswa PGSD), 2013.

[11] A. P. Wardhanie, "PERANAN MEDIA DIGITAL DALAM MEMPERTAHANKAN BUDAYA LOKAL INDONESIA DI ERA GLOBALISASI," Prosiding Strengthening Local Communities Facing The Global Era, pp. 348-354, 2017.

[12] A. Sani, "Tak lagi antik, Rumah Lontiok kini lapuk dan tidak terawat," 10 May 2016. [Online]. Available: https://www.merdeka.com/peristiwa/taklagi-antik-rumah-lontiok-kini-lapuk-dan-tidak-terawat.html.

[13] I. Ismar, "Terbengkalai, HAM-Luwu Timur Desak Bupati Selesaikan Rumah Adat Wotu," 3 March 2018. [Online]. Available: https://makassar.tribunnews.com/2018/03/03/terbengkalai-ham-luwutimur-desak-bupati-selesaikan-rumah-adat-wotu.

[14] Saldy, "Memprihatinkan, Begini Kondisi Rumah Adat di Benteng Somba Opu, Lihat Foto-fotonya," 23 January 2018. [Online]. Available: https://makassar.tribunnews.com/2018/01/23/memprihatinkan-beginikondisi-rumah-adat-di-benteng-somba-opu-lihat-foto-fotonya.

[15] Widiastuti, "ANALISIS SWOT KERAGAMAN BUDAYA INDONESIA," Jurnal Ilmiah WIDYA, vol. 1, no. 1, pp. 8-14, 2013.

[16] A. S. Nery and A. C. Sena, "Efficient A* Co-processor for Reconfigurable Gaming Devices," 17th Brazilian Symposium on Computer Games and Digital Entertainment, Volume 2018-November, 6 February 2019, Article number 8636904, pp. $97-106, \quad 2019$. https://doi.org/10.1109/SBGAMES.2018.00021

[17] M. D. Kickmeier-Rust and A. Holzinger, "Teaming up with artificial intelligence: The human in the loop of serious game pathfinding algorithms," 7th International Conference on Games and Learning Alliance,Volume 11385 LNCS, 2019., pp. 354-363, 2019. https://doi.org/10.1007/978-3-030-11548-7_33

[18] N. Kidi, B. Kanigoro, A. G. Salman, Y. L. Prasetio, I. Lokaadinugroho and A. A. Sukmandhani, "Android Based Indonesian Information Culture Education Game," 2nd International Conference on Computer Science and Computational Intelligence 2017, pp. 99-106, 2017. https://doi.org/10.1016/j.procs.2017.10.015

[19] A. Setiawan, A. Handojo and R. Hadi, "Indonesian Culture Learning Application based on Android," International Journal of Electrical and Computer Engineering (IJECE). Vol. 7, No. 1, February 2017, pp. 526-535, 2017. http://doi.org/10.11591/ijece.v7i1.pp526-535

[20] R. Rizky and T. Wibisono, Mengenal Seni \& Budaya Indonesia, Jakarta: CIF (Penebar Swadaya Group), 2015.

[21] K. Yusof and M. Man, "Efficiency of Flat File Database Approach in Data Storage and Data Extraction for Big Data," Indonesian Journal of Electrical Engineering and Computer Science, pp. 460-473, 2018. http://doi.org/10.11591/ijeecs.v9.i2.pp460-473

[22] E. Adams, Fundamentals of Game Design (3rd Edition), New Riders Publisihing, 2014.

[23] B. Shneiderman, C. Plaisant, M. Cohen, S. Jacobs, N. Elmqvist and N. Diakopoulos, Designing the User Interface: Strategies for Effective HumanComputer Interaction (6th ed.), Pearson, 2016. 